Open Access

\title{
Sri Chinmoy on the nature and goals of contemplative practice
}

Kusumita P. Pedersen(1)

Correspondence: kusumita@igc.org Emerita of Religious Studies, St. Francis College, 165-20 Chapin Court, Jamaica, NY 11432, USA

\begin{abstract}
Sri Chinmoy (1931-2007) has written extensively on the concrete details of contemplative practice as well as its purpose in the wider context of yoga as a system of spiritual disciplines leading to God-realization. The paper summarizes his teachings with an emphasis on how contemplative practice is done and how it works in attaining its goals. Sri Chinmoy distinguishes between concentration, meditation and contemplation (the last a term he reserves for highly advanced practice). While not offering a single "technique" but rather a toolbox of many techniques from which the practitioner can choose, he commends a particular basic approach or method while always recognizing the validity of other approaches. On the path of love, devotion and surrender, Sri Chinmoy emphasizes a focus on the heart and cultivation of aspiration, an inner cry for self-transcendence. In actual practice, this approach attenuates the ego and eventually brings illumination into a person's entire consciousness. The paper explains how this process relates to samädhi, which is described, and the difference between samädhi and realization. The paper also touches on the relation between meditation and action and the further goal, beyond God-realization, of "God-manifestation" or integral transformation of the individual, human society and the evolving cosmos.

Keywords: Aurobindo, Chinmoy, Contemplation, Contemplative practice, Godrealization, Heart, Panentheism, Ramakrishna, Samādhi, Spirituality, Vivekananda, Yoga
\end{abstract}

\section{Introduction}

Sri Chinmoy declares,

In this world there is only one thing worth having, and that is illumination... The highest illumination is God-realisation. This illumination must take place not only in the soul, but also in the heart, mind, vital and body. God-realisation is a conscious, complete and perfect union with God. ${ }^{1}$

Sri Chinmoy understands God to be the infinite Source and Ground of all that exists, which is both personal and impersonal and also dwells in each being as its true self; the Supreme is both transcendent and immanent. Indeed, Sri Chinmoy often speaks of "God the Creator" and "God the creation," affirming that, 
The purpose of life is to realise the highest Truth, to reveal the highest Truth, and to manifest the highest Truth. Our earthly existence is the opportunity to grow and develop both within and without. Inwardly, we grow in our realisation of Truth, and outwardly we grow into the manifestation of our realisation. ${ }^{3}$

This growing - the process of realization, revelation and manifestation - is yoga, according to Sri Chinmoy.

What is Yoga? Yoga is the language of God. If we wish to speak to God, we have to learn His language... If we wish to see through God's Eye and feel through His Heart, if we wish to live in God's Dream and know God's Reality, if we wish to possess the Breath of God, and finally if we wish to become God Himself, Yoga will beckon us. ${ }^{4}$

Born Chinmoy Kumar Ghose in 1931 in the village of Shakpura in Chittagong, East Bengal, Sri Chinmoy was the youngest of seven children in a prosperous and welleducated Kāyastha family. ${ }^{5}$ He was himself beckoned to the spiritual life at an early age, and years later recalled, "I have known intuitively, since my early childhood, that there is a deeper Self within me." ${ }^{6}$ His parents, Shashi Kumar Ghose and his wife Yogamaya, were orthodox Hindus, observing annual festivals and other customs and practices in a traditional manner. Each of the child's parents and older siblings was engaged in the practice of prayer and meditation, and in this setting his own spirituality was formed and nourished. The oldest child in the family, Hriday Ranjan, at 21 became a disciple of Sri Aurobindo and the Mother, Mirra Alfassa, leaving home to join their Ashram in Pondicherry when his youngest brother was still an infant. The whole family soon became disciples of Sri Aurobindo and the Mother, and made the journey from Chittagong to Pondicherry several times. Chinmoy's childhood was a deeply happy one, spent roaming the countryside and exploring the city of Chittagong, where his father worked, when he was not in school or in the bosom of his family.

This idyllic time came to an end when Chinmoy was eleven. Shashi Kumar died late in 1942 and Yogamaya passed away a year later. In April 1942 on the western front of World War II Asia, Burma had fallen to Japanese forces, which then began to bomb Chittagong and the Bay of Bengal. Severe food shortage developed, leading to famine throughout Bengal in 1943. ${ }^{7}$ Under these drastic circumstances, the Mother of the Sri Aurobindo Ashram changed the policy that did not allow children to become residents. With those of his brothers and sisters not already there, Chinmoy joined the Ashram in July 1944, just before his thirteenth birthday. His six brothers and sisters remained there for the rest of their lives and none ever married. They were a close-knit family of spiritual practitioners.

Upon his arrival in the Ashram, the young Chinmoy plunged into the practice of meditation. As he has recounted, at once there took place a great opening of his inner life, with a flood of spiritual experiences that rapidly increased in height and depth, culminating in samädhi and God-union. Some of these early experiences are recorded in his autobiographical writings and in poems such as The Absolute, the first lines of which are: 
No mind, no form, I only exist;

Now ceased all will and thought.

The final end of Nature's dance,

I am It whom I have sought. ${ }^{8}$

In his 14th year, by his own account, he became fully conscious of the spiritual realization attained in his previous lives, saying that, "it was just like turning the pages of a book that I had already devoured." In the years that followed he would expand and solidify this realization, meditating many hours a day. At the same time he continued his studies, excelled in athletics, and wrote poetry and prose. For 8 years he was the secretary of the well-known Bengali man of letters, Nolini Kanta Gupta, who had been one of Sri Aurobindo's first disciples and was Secretary of the Ashram. ${ }^{10}$ During this time he translated dozens of Nolini's essays and articles from Bengali into English. ${ }^{11}$ After 20 years at the Ashram, Chinmoy travelled to New York in 1964, answering an inner call to share his knowledge with spiritual seekers in the West and later throughout the world.

For more than 40 years until his passing in 2007 he gave talks, wrote, composed and performed music, created innovative sports programs, and engaged in dialogue with people from all walks of life while teaching a growing community of disciples. Beginning in 1970 he led meditations for peace at United Nations headquarters in New York $^{12}$ and was a strong supporter of the interfaith movement. ${ }^{13}$ He became known as an advocate of peace and the exponent of a dynamic spirituality of transformation accepting all areas of human endeavor as venues of spirituality. His teachings on contemplative practice are founded on his own inner experience and articulated in his distinctive poetic and philosophical voice. He draws from the works of his teacher Sri Aurobindo, and also from Sri Ramakrishna and Swami Vivekānanda, with whom his family felt a strong connection and whose influence also permeated the life of the Ashram. ${ }^{14}$ Sri Chinmoy powerfully affirms the worldview of these immediate forebears, and like them he looks to the Upanișads and the Bhagavad Git $\bar{a}$ as fountainheads of Indian tradition. ${ }^{15}$ Allowing for differences of style and vocabulary, as well as areas of special focus, we may say that this shared worldview includes the following features: a concept of the Divine as a plentitude of being having many aspects - with form and formless, personal and impersonal, and both within and beyond the world ${ }^{16}$; pluralism of the yogas or spiritual paths, each of which is a valid approach to realization; acceptance of evolution as a cosmic progress which unfolds aspiring consciousness from within matter, taking yoga to be part of this progress; and acceptance of the manifested world and the necessity of service to others, working to transform not only the individual but society at large. This is, needless to say, the briefest outline of an exceedingly rich and nuanced subject, but provides some general context for what follows. The exposition of contemplative practice given here is based on Sri Chinmoy's extensive writings and is aided in understanding by my own observation and practice under his guidance as his student since $1971 .^{17}$

\section{Basic elements of contemplative practice}

The diverse traditions of yoga include concentration, meditation, prayer, and mantra repetition along with other disciplines that support these contemplative practices. 
Sri Chinmoy prioritizes meditation but does not recommend any particular technique, and in fact hardly ever uses the term "technique." On one occasion he transposed the word into a context far beyond its usual one, saying, "Our technique is the practice of conscious surrender to God's Will, divine love for God, and constant self-dedication to the Supreme within us. This is the technique which my disciples follow." ${ }^{18}$ He nonetheless explained a good many specific procedures and exercises for meditation, which comprise a toolbox of techniques from which the practitioner can choose (his students have collected many of these in a book called 101 Meditation Techniques from the Writings of Sri Chinmoy ${ }^{19}$ ).

In addition to regularity, there are certain basic practices that are necessary for everyone if meditation is to be effective, such as keeping the spine straight, breathing slowly and regularly, having a regular time to meditate early in the morning, and if possible, setting apart a special sacred space used only for meditation. Sri Chinmoy also recommends meditation with the eyes half open to prevent drowsiness and to maintain a connection with the outer world. ${ }^{20}$ Beyond this, however, each practitioner learns over time through personal experience and from inner guidance what works best for her or him. Sri Chinmoy says,

Each person has his own way of meditating. What actually happens is that sometimes an individual gets from within himself a kind of meditation.

An inner being comes forward and tells the individual to pray or meditate in this or that way, that this or that will help...When you have a teacher, you are extremely lucky, especially if the teacher is a genuine one. If you don't have a teacher, but you have genuine aspiration, God within you will tell you the correct meditation. ${ }^{21}$

The real inner voice that gives true guidance can be recognized because it brings "a feeling of inner joy or peace, where there are no questions or problems or doubts." 22 While stating that a qualified teacher can be of enormous help to the aspirant, Sri Chinmoy at the same time insistently maintains throughout his writings that ultimately the real Guru, for everyone, is the Supreme.

\section{Concentration and meditation}

Sri Chinmoy speaks of three stages of contemplative practice: concentration, meditation, and contemplation. ${ }^{23}$ While lower stages of meditation may admit some kinds of thought, namely thoughts that help one progress spiritually, in the higher levels of meditation there is no thought at all. The ordinary or unillumined "physical mind," the mind enmeshed in and governed by experience of the physical world, is by nature limited, limiting, and divisive. It has its appropriate and necessary functions, but is incapable of attaining higher or deeper levels of consciousness (here I bracket discussion of the spatial-ontological language of "higher" and "deeper"). ${ }^{24}$ Thus the mind must be controlled, eventually silenced and become obedient to the heart, which plays a central role in Sri Chinmoy's teachings. Concentration, the achievement of a one-pointed awareness, is therefore the prerequisite of meditation practice, especially in the initial stages. He describes concentration as follows: 
Concentration is the surest way to reach our goal, whether the goal is God-realisation or merely the fulfillment of human desires. A real aspirant sooner or later acquires the power of concentration either through the Grace of God, through constant practice or his own aspiration.

When we concentrate, we are like a bullet entering into something or we are like a magnet pulling the object of concentration toward us. At that time we do not allow any thought to enter our mind, whether it is divine or undivine, earthly or heavenly, good or bad. In concentration the entire mind has to be focused on a particular object or subject. ${ }^{25}$

Simple concentration exercises might be focusing on a candle flame, one's fingertip, or a word which is repeated. Sri Chinmoy advises, "When you want to practice concentration, you should choose something that gives you immediate joy." 26 Activities requiring practice, discipline and focused attention, such as musical performance or athletics, can also help develop concentration.

When the mind has been quieted to some extent, meditation proper becomes possible. In meditation consciousness is enlarged and identification with the object of one's meditation is developed. Sri Chinmoy explains:

When we concentrate, we focus our attention on one particular thing...But when we meditate, we feel we have the capacity deep within us to see many things, deal with many things and welcome many things all at the same time. When we meditate, we try to expand ourselves, like a bird spreading its wings. We try to expand our finite consciousness and enter into the universal Consciousness where there is no fear, jealousy or doubt but only joy, peace and divine power. Meditation means our conscious growth into the Infinite. When we meditate, what we actually do is to enter into a vacant, calm, silent mind and allow ourselves to be nourished by Infinity itself. When we are in meditation, we only want to commune with God. ${ }^{27}$

Intention is at the core of meditation practice. Why am I meditating? And what am I meditating on? The highest goal of yoga is God-realization and for all who aspire to this goal, yoga or "the spiritual life" as Sri Chinmoy calls it, is a process of transformation.

For Sri Chinmoy, this transformation calls for an ongoing cultivation of positive qualities such as peace, light, joy, and love, as well as the purification of negative qualities which are their opposites. Within this process, each aspirant develops his or her own unique way of meditation suited to his or her disposition and circumstances, as already mentioned. Accordingly the individual practitioner must discern what qualities he or she needs to cultivate at a given moment as well as in the long run, and meditate on these qualities. Thus in Sri Chinmoy's instructions for meditation, imagination and invocation related to the practitioner's intention and need are continually mentioned. Imagination is an important power of thought that can and should be employed in yoga. Sri Chinmoy says, "Imagination is not / A whim of the mind. / It is a reality in its own right." ${ }^{28}$ One can use imagination to access a sought-for reality in the many realms of consciousness. Thus in describing meditation 
procedures Sri Chinmoy very often says, "try to feel that...," encouraging students to invoke a certain image and experience, and through "feeling" to identify with and assimilate a particular quality found there.

To give a few examples from the many meditation procedures Sri Chinmoy has offered, here is a simple meditation on peace. One should try to feel that as one breathes out, one is breathing out all of one's stress, worry, and frustration. Then one should try to feel, as one breathes in, that one is breathing in peace (a good meditation at the end of a working day). If one feels tired, Sri Chinmoy suggests, "Imagine a blue-green forest or field, and feel that you are walking through it. Then, no matter how tired you are, you will feel energized" (in a more elaborate meditation to overcome fatigue one imagines breathing in cosmic energy through the eyes, ears, forehead and other parts of the body). ${ }^{29}$ These meditations, along with many more, engage the individual's imagination to increase positive or "divine" qualities and to evoke the more advanced experiences towards which contemplative practice is aiming.

\section{Prayer and mantra}

Sri Chinmoy often speaks of "prayer and meditation" together in one phrase indicating that they are joint practices and observes that many saints have realized God solely through prayer. ${ }^{30}$ This naturally does not mean petitionary prayer for the fulfillment of ordinary desires, but prayer for those things that will expedite spiritual progress. "If we want to differentiate between prayer and meditation," Sri Chinmoy says, "prayer is the conscious ascent of the human consciousness and meditation is an invitation to the Infinite or an offering to the Infinite." ${ }^{31}$ A special kind of prayer may appear spontaneously in very high states of meditation when the mind is totally silent and "light itself automatically forms its own thoughts and ideas," which may even be without words. ${ }^{32}$

Sri Chinmoy has composed hundreds of prayers and upholds the indispensable role of prayer. He often says that the highest prayer is that of Jesus, "Thy Will be done." Rather than requesting something for oneself or others, one asks that God's Will be done in God's own way. At the core of Sri Chinmoy's philosophy is surrender, and until one unites one's own will with God's Will in surrender, there is neither complete oneness nor the fullness of peace. In an early talk he says, "If we can surrender in absolute silence, we shall ourselves become the Reality of the Real, the Life of the Living, the Centre of true Love, Peace and Bliss. We shall become an incomparable blessing to ourselves." ${ }^{33} \mathrm{He}$ comments that while "Everything about love, devotion and surrender is written in the Bhagavad Gita," these norms are found in many traditions. ${ }^{34}$ One might even aver that cross-culturally, in theistic spiritualities that speak of love, surrender or self-offering is likely to assume a prominent place.

How then to know what God's Will is? On one occasion Sri Chinmoy offered a detailed meditation when asked how to make correct decisions based on inner guidance.

If you want to make the correct decision, you have to meditate most soulfully for at least ten minutes. During this time, you must not have any thought good or bad. The mind has to be completely empty. After meditating for about ten minutes, you will bring tremendous will-power from the third eye. Then you will try to uncover your heart chakra. If you feel that there is 
something covering your heart chakra like a lid, you will just uncover it.

Once you uncover the heart chakra, you will receive a whisper. That whisper will come in the form of light or in your own language. It will not form a sentence - only one word. The light will be connected with your vision-eye [the third eye] and the connection will be there inside the heart. There we do not form sentences. But from that one syllable or one word you will be able to correctly get the message and that will be your final and infallible decision. ${ }^{35}$

Here one sees again the phenomenon of meaning appearing from the midst of silence, as in the case of the special kind of prayer previously mentioned. Given the great importance of discerning God's Will along with the challenge of doing so in everyday life, Sri Chinmoy has discussed different approaches to the question of knowing the divine Will. In general, it is needful to pray regularly to do God's Will, which brings us back to prayer and its importance. One should also attend to the messages of the heart rather than those of the mind, as will be explained further below, and again, a qualified teacher can help significantly. Meditation differs from prayer because rather than asking for anything, one throws oneself into a sea, as it were, of divine qualities where any and all of one's needs can be fulfilled. One enters into a larger reality or invites it to enter into one's own being.

Concerning mantra, Sri Chinmoy observes that each mantra has a particular effect, and thus the use of mantra, like prayer, differs from meditation and for a similar reason - prayer seeks a specific result, while meditation is expansive and open to myriad "results" including those which may be unexpected. For Sri Chinmoy, the mantra that goes beyond limitations of particularity is AUM, or OM, "the mother of mantras," which, he says,

...is the soundless sound. It is the vibration of the Supreme. It is a single, indivisible, ineffable sound. When we hear the soundless sound within, when we identify with it, when we live within it, we can be freed from the fetters of ignorance and realize the Supreme within and without. ${ }^{36}$

This soundless sound can be heard within one's heart, where its source is located. It attunes the practitioner to a plane of consciousness where cosmic harmony is perceived.

AUM is God's sound. Every second God is creating Himself anew inside AUM. This sound He uses to create the world; this sound He uses to preserve the world; this sound He uses to transform the world. ${ }^{37}$

First known in Vedic texts, AUM is not only prevalent in Hindu prayer, ritual, and meditation, but is also found in Buddhism, Jainism, and Sikhism. Finnian McKean Moore Gerety has traced the emergence of AUM over one thousand years from its occurrence in different branches of the Veda to an "exalted position" as a pan-Vedic sacred syllable which is "the sonic essence of the Vedas and the audible realization of their supreme theological principle (brahman)" marked by its "cosmogonic potency." ${ }^{38}$ In our context here of contemporary contemplative practice, it is important to note not only AUM's salience 
in the Upanișads and the Bhagavad Gitā $(8.13,10.25,17.24)$ but also its mention by Patañjali in the Yoga Sütra, as this text is studied worldwide by yoga practitioners and explicitly recommends the repetition of AUM. It states: "Its [Iśvara's] expression is pranava (om). Repetition of it [results in] cultivation of its purpose. Thus, inwardconsciousness is attained and obstacles do not arise" (1.27-29). ${ }^{39}$ Christopher Chapple comments,

One of the great feats of Indian philosophy is its penchant for pointing to the unspeakable without naming it...Purușa is the silence prior to all sound. Ísvara, referred to as the "pranava (om)," is the closest of all approximations to purusa and hence an appropriate object of meditation. Om is a "saying" that is simultaneously no-saying and all-saying, the closest sound to silence. ${ }^{40}$

In the modern period, eminent spiritual teachers have held up the importance of AUM. In his conversations, Sri Ramakrishna often refers to AUM and says, "By following the trail of Om you attain Brahman, of which the word is the symbol;" for AUM as cosmogonic sound, he gives the illustration of the striking of a gong, at the sound of which "Waves begin to rise, the Relative rises from the Absolute; the causal, subtle and gross bodies appear out of the Great Cause; from Turiya [the transcendent reality, or consciousness of it] emerge the states of deep sleep, dream and waking." ${ }^{41}$ Sri Aurobindo similarly describes AUM as,

the mantra or expressive sound symbol of the brahman in its four domains from the turiya to the external or material plane (i.e., the outward looking, the inward or subtle, and the superconscient causal - each letter A, U, M indicating one of these three in ascending order and the whole bringing out the fourth state, turiya); used as an initiating syllable pronounced as a benedictory prelude and sanction. ${ }^{42}$

Swami Vivekānanda also emphasizes its significance, not only in Raja Yoga, his commentary on Patañjali, but in Bhakti Yoga and elsewhere; in a lengthy 1897 talk on "The Vedanta" he exhorts his listeners to know that "You are the Om; know the secret of this Tattvamasi [You are That]." In sum, with this strong current of transmission from India to the West, both an acquaintance with AUM's meaning and adoption of its use as a mantra in meditation practice have now become widespread. ${ }^{44}$ For those concerned with yoga as a spiritual discipline today, this ancient mantra has retained its power and applicability.

\section{Aspiration and transcendence of the ego}

The key to both prayer and meditation is aspiration. ${ }^{45}$ Aspiration is the longing for a higher, deeper, and more fulfilling reality, imaged as a "cry," a "hunger" or a "flame" mounting within us. It is the principle of self-transcendence innate in all existence. Sri Chinmoy holds that the Godhead Itself, Sat-Cit-Ānanda, is always going beyond Its own Infinity, and throughout his writings calls God "the ever-transcending Beyond." He says, "Brahman, the infinite Consciousness, is always in the process of transcending the limitless expanse of the Beyond." ${ }^{47}$ When the Supreme creates the universe, the process of the One becoming the many is an expression of God's own Aspiration, the dynamism of self-transcendence inherent in the Divine Itself: "In the world of 
aspiration, God, who was at the very beginning one, wanted to become many. When He wanted to become many, He sang the song of self-transcendence. By fulfilling Himself in the world of multiplicity, He offers us the dance of perfection." ${ }^{48}$ Within each of the numberless finite beings in the manifested world, there is unconscious or conscious aspiration. In the evolutionary worldview mentioned earlier, aspiration is the driving force of all evolution, progress and creativity. In yoga, conscious spiritual aspiration is the "inner urge" that moves contemplative practice forward.

Whether through the yoga of knowledge of reality, the yoga of love and devotion, or the yoga of selfless service to others - or some combination of these - to unite oneself with the Supreme one must transform the ego, or sense of self. Sri Chinmoy explains,

There is a Self that is the transcendental Self - the silent Self. When we go deep within, in our highest, most sublime meditation, we discover this Self...The self that we use in our day-to-day life, in our earthly reality, is the self of the physical world, of the mental and of the vital world. Each world has a kind of self." ${ }^{49}$

Self-realization and God-realization are equivalent because God the One, when immanent in the many, is the individual soul: the atman or jiva. The finite and illusory selves of the physical, vital (emotions and life-energy) and mental existence must be set aside if one is to perceive the transcendental Self. One of Sri Chinmoy's songs, composed in both Bengali and English, gives a condensed expression of this: "Khudra āmire häraite habe brihat àmire labhite - I must lose the little 'I' to get the big 'I.' "50 Because the construction of the limited ego depends to a great extent on the physical mind, the control of thought is indispensable in contemplative practice directed to realization. A poem says: "The physical mind / Not only has the barrier / But also is the barrier itself. / If you want to surmount the physical mind, / Then go to the beautiful garden / Of lovelight inside your heart. ${ }^{n 1}$

The oneness of all existence cannot be seen intuitively or felt through love until the mind's maintenance of the illusion of separateness has been dismantled. On the path that Sri Chinmoy teaches of love, devotion and surrender, the fastest and most effective way to accomplish this is to enter into the heart and to remain in the consciousness of the heart as much as possible. By "the heart" he means the heart center or chakra that is part of the "subtle body" in many yoga traditions. The heart is where the soul abides and possesses the qualities of light, joy, peace, and love naturally because of its proximity to the soul. Further reflection on the ontology of the heart as the boundary between the world and the transcendent is beyond the scope of this essay, but let us note that the heart is a faculty of knowledge as well as the center of love, affection, and compassion. Sri Chinmoy often refers to the heart as knowing through "feeling" - a special kind of psychic emotion distinct from, and more subtle than, the ordinary emotions of the unillumined vital. But he speaks as well of "the eye of the heart" (an expression also found in Sufism) and says, for example, "To see the ultimate Truth / We must open / Our heart-eye," and "The vision / Of the heart-eye / Is unlimited." 52 Therefore Sri Chinmoy offers an array of meditations intended to focus consciousness on the heart, open the heart, and bring the heart's qualities of love, peace, and joy into the outer being, that is, into the mind, the vital, and the body. One may imagine that one is a young child, playing spontaneously in a flower 
garden which is the heart. Or one may visualize a flower in one's heart, then that one's heart is itself the flower, which is opening petal by petal, and then feel that one's body and the heart-flower have become co-extensive and that one's entire body is permeated with the fragrance of the flower. Additionally, one may visualize the sun rising within one's heart, or the vast sky within one's heart, ${ }^{53}$ images as old as the Upanișads, which speak of the soul as located in the heart ( $h r d, h r d a y a)$ on numerous occasions. ${ }^{54}$

Contemplative practice attenuates the ego by reducing or removing its components and the supports that energize it, correcting thoughts that reinforce the sense of a separate self divided from others, and instead constantly directing awareness to a larger reality through increased love and devotion. It is here that traditional ascetic practices of restraint have a role to play. If the mind surrenders to the heart - by no means easy to bring about - and receives light and instruction from the soul through the heart, then the emotions, vital energy, and the body can also receive illumination in the course of time. Love may here be defined as the affective awareness or "feeling" of an ontological oneness (oneness meaning unity-in-difference). Devotion intensifies and sweetens love and impels it to action; surrender is an active volitional identification. These three phases of love move towards a more and more complete consciousness of oneness with the Divine that is already actual in being, but not yet known. In full realization, love and knowledge converge.

\section{Contemplation}

In Sri Chinmoy's terminology, the most advanced stage of contemplative practice is called contemplation. ${ }^{55}$ Contemplation is done "when one is very advanced in the spiritual life...Contemplation is required before God-realisation, it cannot be ignored or avoided," but before the practice of contemplation both concentration and meditation have to be perfected. ${ }^{56}$ Contemplation brings one to the verge of full realization and is the mode of concrete union of being, beyond less complete experiences of identification. Sri Chinmoy says:

The Truth we have seen and felt in meditation, we grow into and become totally one with in contemplation...Contemplation means our conscious oneness with the infinite, eternal Absolute. Here the creator and the creation, the lover and the beloved, the knower and the thing known, become one. One moment we are the divine lover and God is the Supreme Beloved. The next moment we change roles. In contemplation, we become one with the Creator and see the whole universe inside us. At that time, when we look at our own existence we don't see a human being. We see something like a dynamo of peace, light and bliss.

In contemplation, the entire universe and farthest Goal we feel deep inside ourselves. When we are contemplating, we feel that we are holding within ourselves the entire universe with its infinite Light, Peace, Bliss and Truth. There is no thought, no form, no idea; it is all one stream of consciousness. In our highest contemplation we feel that we are nothing but Consciousness itself; we are one with the Absolute. ${ }^{57}$

In the foregoing passage it is mentioned three times that in contemplation we "see" or "feel" the entire universe "inside" ourselves, and the description below of nirvikalpa 
samädhi says that in this state the whole universe is seen as a dot inside one's "vast heart." Such yogic experiences of expanding into a vast divine consciousness correspond to certain major themes of panentheism: that the world is within God, that God is more than the world, and that God is conscious. This is not surprising as it is recognized that Indian traditions, which generally acknowledge a possible relation of mystical experience and philosophical construction, house a wealth of panentheistic views and resonances. Especially relevant in this context is that Sri Chinmoy's own spiritual teacher, Sri Aurobindo, whose philosophy is yoga-based, is considered a panentheist by a number of scholars. ${ }^{58}$

Even though contemplation is highly advanced, Sri Chinmoy has offered a visualization that may give some idea of this experience: "Try to imagine a golden being, and feel that he is infinitely more beautiful than the most beautiful child that you have ever seen on earth. This being is your beloved Lord Supreme." One then imagines the existence of oneself as the lover and the golden being as the Beloved on the top of a mountain in the Himalayas or at the bottom of the Pacific Ocean, "whichever is easier..." Next, one is instructed to feel one's self as the Beloved Supreme and to imagine that the golden being is the divine lover. "It is like a game of divine hide-and-seek. When you become the Supreme Beloved, the divine lover seeks you, and when you become the divine lover, you search for your Beloved Supreme." ${ }^{59}$ Sri Chinmoy's description of contemplation resembles his account of certain states of samādhi, to which we now turn.

\section{Samādhi and realization}

There are a number of "minor samädhis" and the highest of these is savikalpa samädhi, in which "the conception of time and space is altogether different...there are thoughts and ideas coming from various angles, but they do not affect you." There is a tremendous gap between this state and the higher stage of nirvikalpa samädhi. In a remarkable passage in his book The Summits of God-Life: Samadhi and Siddhi ${ }^{61}$ Sri Chinmoy attempts to describe this experience, first emphasizing that "the consciousness of nirvikalpa samädhi can never be adequately explained or expressed. The revelation of the experience can never be like the original experience." After this admonition, he continues,

In nirvikalpa samädhi we have no mind. We see the Creator, the Creation and the Observer as one Person. There the object of adoration and the person who is adoring become totally one; the Lover and the Beloved become totally one. We go beyond everything and at the same time we see that everything is real... when we enter into nirvikalpa samādhi, the first thing we feel is that our heart is larger than the universe itself...When we are in nirvikalpa samādhi, we see the universe like a tiny dot inside our vast heart." ${ }^{n 2}$

What does it mean that the whole universe is seen within one's "vast heart"? It may be said that the heart center or chakra, like other centers of the "subtle body" as described in yoga traditions, links an individual to the macrocosmic dimension. We have already seen that Sri Chinmoy gives great importance to the spiritual heart, which can be developed to open the practitioner's awareness to the cosmic and universal. $\mathrm{He}$ compares this process to the growth of a seed into a tree, and says, "When we 
have developed the spiritual heart, at that time we come to realize our identity with the Mother and Father of the universe." ${ }^{63} \mathrm{He}$ adds that in nirvikalpa samädhi there is unimaginable Bliss and Power, emphasizing again that these cannot be expressed in words. ${ }^{64}$ Although these pinnacle experiences are beyond verbal expression, Sri Chinmoy has composed many poems seeking to give some intimation of them, such as The Absolute, quoted earlier, or this Bengali song:

Nāi, nāi, nāi, àmi àr nāi Shudhu āchhe ek chhāyā Sahāsà sonāli ālor jhalake Seo je härai kāya
No, no, no! I no longer exist.

What exists is only a fragile shadow.

And that, too, has lost its existence-life

In a golden lightening spark. ${ }^{65}$

The awakening of the kundalini and the opening of the chakras may result in experiences like those just described, but no experience as such as is equivalent to realization. There is an enormous difference between samādhi and full realization; one may enter samädhi and then leave it and return to ordinary consciousness, while God-realization is a lasting transformation. In contrast to samādhi, "In realisation, one's whole consciousness has become inseparably and eternally one with God."

God-realization is not merely an experience, but a conscious and also permanent oneness with the Supreme, who is and has always been our highest Self. "Self-awareness / And / Conscious oneness with God / Are not / Two different things," ${ }^{67}$ Sri Chinmoy says. The phrase "another God" occurs throughout his writings, and in one poem he asks, "What is it like to be another God? / It is like attaining / Not only your unattained self / But also your unattainable Self." ${ }^{\text {" }}$ One's entire being including the mind, vital, and body receive this God-consciousness in an integral and irreversible illumination. In the process of yoga as described by Sri Chinmoy, concentration enables us to lay aside whatever is an impediment, meditation enables us to "see," "feel," and then expand and grow into the divine Reality, while contemplation enables us to become that Reality in consciousness.

Beyond God-realization lie the further goals of revelation and manifestation. "God-manifestation" - the ever-transcending transformation and divinization of the world - is of central importance in Sri Chinmoy's philosophy. It draws together all aspects of his spiritual vision and ethical concerns, and here only a brief indication can be given. Sri Chinmoy compares realization to touching a tree, and then climbing it and picking the fruit (something he did countless times in his childhood). If I possess the fruit, this is realization. If I take it out and show it to others, this is revelation. To share the fruit with others so that they eat it themselves and digest it is manifestation ${ }^{69}$. All the varied activities of human life can become ways of sharing the fruit with others and can be places of contemplative practice. "Meditation in action is manifestation," Sri Chinmoy says. "God has to occupy one's mind, and in this state of divine concentration," one should serve the world while seeing the Divine in all. ${ }^{70}$

The very purpose of creation, the divine Play or Lìlä, is a cosmic progress in which God's qualities are increasingly assimilated and become more and more concretely present in the world. Because this transformation is the ultimate goal of humans and all life, dedication to the process of God-manifestation is an inseparable part of conscious aspiration and contemplative practice in the teachings of Sri Chinmoy. 
"Realisation is not / The end of the road," Sri Chinmoy says. "It is only a challenge / On the way to God's / Perfect Manifestation on earth."71

\section{Conclusion}

In conclusion, all of the contemplative practices described in this essay, from the most basic to the most advanced, are to be done in the midst of life. Sri Chinmoy strongly holds that meditation and prayer must not be separated from our outer experience. This is because the goal of God-manifestation requires acceptance of the world, and what is not accepted cannot be transformed. He declares, "We have to accept life and then we have to transform it to make it a perfect instrument of God...if we do not accept the world, we can never transform it. If something is imperfect, only by touching it, making it part and parcel of our lives, can we make it perfect." ${ }^{72}$ If we want to make the world better, we have to live in the world. Moreover, seclusion or withdrawal do not help us to progress towards realization - for that what is needed is aspiration, self-offering, and love for God. To be sure, every practitioner does need to establish meditation in quietude and can then draw from its reserves of peace and light while immersed in the day's activities, but as she or he becomes more advanced will develop the capacity to also meditate even while involved in action, and in spite of all distractions and problems. We should not fear the world or reject it because of its darkness and ignorance, but be spiritual heroes as we aspire for our own illumination and work for the common good, dedicating each action to God. As Sri Chinmoy often says, we should "love God the Creator and serve God the creation."

A fully realized person is constantly united with the inner reality of truth and light and is at all times conscious of it, yet this person too is engaged in striving as he or she embraces the challenges of revelation and manifestation. At all stages, contemplative practice builds a bridge between the inner and outer realities. Meditation is practiced not only in silence, but eventually also in sound. Its outer expression guides and empowers the seeker's service to the world, without which there can be no transformation. When the divine qualities of the inner life can be manifested in the outer world, it will then be changed into a world of perfection and fulfillment.

\section{Endnotes}

${ }^{1}$ Chinmoy 1974e, i-ii.

${ }^{2}$ See Pedersen 2006. Sri Chinmoy's vision of the Divine can be characterized as panentheistic. For succinct statements of the panentheistic perspective see Biernacki 2014, 3 and Clayton 2010, 184-85; both refer to Charles Hartshorne's "classic definition." See Hartshorne and Reese, eds., 2000, 16-18.

${ }^{3}$ Chinmoy 1978a, 218.

${ }^{4}$ Chinmoy 1996b, 55.

${ }^{5}$ The following account of Sri Chinmoy's early life is based on his autobiographical writings, including Chinmoy 1992, 1994, 1998 and 1996b. Autobiographical passages are also found in many of his other works.

${ }^{6}$ Chinmoy 1996c, 91.

${ }^{7}$ For a detailed analysis of the Bengal famine, see Greenough 1982. 
${ }^{8}$ Chinmoy 1972.

${ }^{9}$ Chinmoy 2015, 786 .

${ }^{10} \mathrm{He}$ has published excerpts from his journal of his years with Nolini as A ServiceSun, A Service Flame, Chinmoy 2003a.

${ }^{11}$ See, for example, Gupta 1970; the essays first appeared in English serially in Mother India, 1961-1963.

${ }^{12}$ See Pedersen 2010b.

${ }^{13}$ See Pedersen 2010a.

${ }^{14}$ On Sri Chinmoy's connection with Sri Ramakrishna and Swami Vivekananda, see Pedersen 2011.

${ }^{15}$ See Chinmoy 1996 .

${ }^{16}$ As already mentioned, a panentheistic view; see Note 3.

${ }^{17} \mathrm{My}$ purpose in this essay is to give a straightforward summary of Sri Chinmoy's account of contemplative practice primarily, with a very condensed statement of the larger worldview in which the practice is embedded. While much that is essential is drawn together in the anthology on meditation (1978b) and his book on samādhi and God-realization (1974e), much else is found throughout his voluminous writings (more than 1500 works), in which poetry is as important as prose for virtually any topic under consideration. I have quoted from a wide range of these works as needed.

${ }^{18}$ Chinmoy 1974b, 81.

${ }^{19}$ Chinmoy 2009.

${ }^{20}$ Chinmoy 1978b, 45.

${ }^{21}$ Chinmoy 1996b, 87-88.

${ }^{22}$ Ibid.

${ }^{23}$ These three correspond roughly to the dhäraña, dhyāna and samādhi of the Yoga Sūtra.

${ }^{24}$ For Sri Chinmoy's discussion of this question, see 1978b, 74-75.

${ }^{25}$ Ibid., 131-132.

${ }^{26}$ Ibid., 143.

${ }^{27}$ Ibid., 133.

${ }^{28}$ Chinmoy 2007, 48.

${ }^{29}$ Chinmoy 1978b, 108-09.

${ }^{30}$ Chinmoy 1974d, 2.

${ }^{31}$ Ibid.

${ }^{32}$ Ibid., 12-13.

${ }^{33}$ Chinmoy 1996c, 21.

${ }^{34}$ Chinmoy 1974f, 13.

${ }^{35}$ Chinmoy 2015, 1135-36.

${ }^{36}$ Chinmoy 1974d, 51.

${ }^{37}$ Ibid., 54; for a general explanation see 47-58.

${ }^{38}$ Moore Gerety 2015, 415, 420.

${ }^{39}$ Chapple 2008, 152.

${ }^{40}$ Ibid., 28.

${ }^{41}$ The Gospel of Sri Ramakrishna 1984 [1942], 404, 653.

${ }^{42}$ Aurobindo 1992, 447. 
${ }^{43}$ Vivekananda 1979, in Raja Yoga in Collected Works, Vol. 1, 217-220; in Bhakti Yoga, in Collected Works, Vol. 3, 56-59; "The Vedanta," Ibid., 426.

${ }^{44} \mathrm{AUM}$ has also occasioned theological reflection drawing on Western and Christian concepts, such as John G. Arapura's identification of AUM as the "self-evoking aspect of Brahman" within his interpretation of the Upanișads as "the Logos (Vāk) in its self-manifestation - and the Logos is the assurance of both thought and mystical experience; it is that which makes them possible." "Spirit and Spiritual Knowledge in the Upanișads." Arapura 1989, 78, 66.

${ }^{45}$ Chinmoy 1974d, 2.

${ }^{46}$ See Pedersen 2006, 171-73.

${ }^{47}$ Chinmoy 2004, 4.

${ }^{48}$ Chinmoy 1976, 11.

${ }^{49}$ Chinmoy 1974a, 104.

${ }^{50}$ Chinmoy 1986, No. 21.

${ }^{51}$ Chinmoy 1982b, No. 4021.

${ }^{52}$ Chinmoy 2003, No. 25, 806; 2002, No. 30, 095.

${ }^{53}$ See Chinmoy 2009, 116-18.

${ }^{54}$ For a discussion of these and other themes, see Olivelle 2006.

${ }^{55} \mathrm{We}$ should bear in mind that in English the terms "contemplation" and "meditation" do not have precise or technical meanings apart from one or another specific religious context.

${ }^{56}$ Chinmoy 1978b, 147.

${ }^{57}$ Ibid., 134-36.

${ }^{58}$ Clayton 2010, Stensell and Phillips 2010, and Murphy 2014. Philip Clayton comments on the connection of spirituality to panentheism: "panentheism fosters its own distinctive spirituality...From yogic practices to Quaker worship, these spiritualities make their own contribution to the storehouse of the world's spiritual practices." 2010, 190-91.

${ }^{59}$ Chinmoy 1978b, 140.

${ }^{60}$ Chinmoy 1974e, 76-77.

${ }^{61}$ The Sanskrit word siddhi means "attainment," "success" or "perfection." It most often refers to the various supranormal or "occult" powers attainable through the practice of yoga, but can also be used to mean the state of enlightenment or realization attained by a siddha or spiritually perfected being. Sri Chinmoy almost always uses the term "realization" but chose to use "siddhi" in the second sense for the title of this book.

${ }^{62}$ Ibid., 82-83.

${ }^{63}$ Ibid., 96.

${ }^{64}$ Ibid., 81-84.

${ }^{65}$ Chinmoy 1975, 87.

${ }^{66}$ Chinmoy 1974e, 85-86.

${ }^{67}$ Chinmoy 1982a, 24.

${ }^{68}$ Chinmoy 1983a, No. 66.

${ }^{69}$ Chinmoy 1974e, 127-28.

${ }^{70}$ Chinmoy 1974c, 47.

${ }^{71}$ Chinmoy 1983b, No. 1800.

${ }^{72}$ Chinmoy 2015a, 718. 


\section{Acknowledgements}

I would like to thank Chidananda Burke, Christopher Key Chapple, Adhiratha Keefe, Jeffery D. Long, Christopher Miller, Mahatapa Palit, Brahmacharini Michelle Rebidoux, Nilima Silver and Swami Yatidharmananda for their helpful comments during the writing of this essay.

\section{Funding}

No funding has been received for the research undertaken to do this article.

\section{Authors' information}

Kusumita P. Pedersen is the sole author of this article.

\section{Competing interests}

The author declares that she has no competing interests.

Received: 14 July 2016 Accepted: 28 October 2016

Published online: 30 December 2016

\section{References}

Arapura, John. G. 1989. Spirit and Spiritual Knowledge in the Upanișads. In Krishna Sivaraman, ed. Hindu Spirituality: Vedas through Vedānta. Vol. 6 of World Spirituality: An Encyclopedic History of the Religious Quest, edited by Ewert Cousins. New York: Crossroad: 64-85.

Aurobindo, Sri. 1992. The Upanishads: Texts, Translations and Commentaries, 2nd ed. Pondicherry: Sri Aurobindo Ashram Trust.

Biernacki, Loriliai. 2014. Introduction: Panentheism Outside the Box. In Panentheism across the World's Traditions, ed. Loriliai Biernacki and Philip Clayton, 1-17. New York: Oxford University Press.

Chapple, Christopher Key. 2008. Yoga and the Luminous: Patanjali's Spiritual Path to Freedom. Albany: State University of New York Press.

Chinmoy, Sri. 1972. My Flute. Jamaica, NY: Sri Chinmoy Lighthouse.

Chinmoy, Sri. 1974a. Fifty Freedom-Boats to One Golden Shore, Part 2. Jamaica, NY: Agni Press.

Chinmoy, Sri. 1974b. Fifty Freedom-Boats to One Golden Shore, Part 3. Jamaica, NY: Agni Press.

Chinmoy, Sri. 1974c. Meditation: Man's Choice and God's Voice, Part 2. Jamaica, NY: Agni Press.

Chinmoy, Sri. 1974d. Prayer-World, Mantra-World and Japa-World. Jamaica, NY: Agni Press.

Chinmoy, Sri. 1974e. The Summits of God-Life: Samadhi and Siddhi. Jamaica, NY: Agni Press.

Chinmoy, Sri. 1974f. Surrender's Unlimited Power. Jamaica, NY: Agni Press.

Chinmoy, Sri. 1975. Supreme, Teach Me How to Surrender. Jamaica, NY: Agni Press.

Chinmoy, Sri. 1976. Self-Discovery and World-Mastery. Jamaica, NY: Agni Press.

Chinmoy, Sri. 1978a. Earth's Cry Meets Heaven's Smile, Book 3. Santurce, Puerto Rico: Aum Press,

Chinmoy, Sri. 1978b. Meditation: Man-Perfection in God-Satisfaction. Jamaica, NY: Agni Press.

Chinmoy, Sri. 1982a. Ten Thousand Flower-Flames, Part 41. Jamaica, NY: Agni Press.

Chinmoy, Sri. 1982b. My Heart's Thirty-two Sacred Secrets. Jamaica, NY: Agni Press, 1982.

Chinmoy, Sri. 1983a. Twenty-Seven Thousand Aspiration-Plants, Part 1. Jamaica, NY: Agni Press.

Chinmoy, Sri. 1983b. Twenty-Seven Thousand Aspiration-Plants, Part 18. Jamaica, NY: Agni Press.

Chinmoy, Sri. 1986. Four Hundred Blue, Green, White, Red Song-Birds, Part 3. Jamaica, NY: Agni Press.

Chinmoy, Sri. 1992. My Father Shashi Kumar Ghosh: Affection-Life, Compassion-Heart, Illumination-Mind, by Madal. Jamaica, NY: Agni Press.

Chinmoy, Sri. 1994. To the Streaming Tears of My Mother's Heart and to the Brimming Smiles of My Mother's Soul, by Madal. Jamaica, NY: Agni Press.

Chinmoy, Sri. 1996a. Commentaries on the Vedas, Upanishads and Bhagavad Gita: The Three Branches of India's Life-Tree. Jamaica, NY: Aum Publications.

Chinmoy, Sri. 1996b. My Consulate Years. Jamaica, NY: Agni Press.

Chinmoy, Sri. 1996c [1970]. Yoga and the Spiritual Life. Jamaica, NY: Aum Publications.

Chinmoy, Sri. 1998. My Brother Chitta, by Madal. Jamaica, NY: Agni Press.

Chinmoy, Sri. 2002. Seventy-Seven Thousand Service-Trees, Part 26. Jamaica, NY: Agni Press.

Chinmoy, Sri. 2003a. A Service-Sun, A Service-Flame, by Chinmoy. 3rd printing. Jamaica, NY: Agni Press.

Chinmoy, Sri. 2003b. Seventy-Seven Thousand Service-Trees, Part 31. Jamaica, NY: Agni Press.

Chinmoy, Sri. 2004. The Oneness of the Eastern Heart and the Western Mind, Part 2. Jamaica, NY: Agni Press.

Chinmoy, Sri. 2007. My Christmas-New Year-Vacation-Aspiration-Prayers, Part 50. Jamaica, NY: Agni Press.

Chinmoy, Sri. 2009. 101 Meditation Techniques from the Writings of Sri Chinmoy. Jamaica, NY: Aum Publications.

Chinmoy, Sri. 2015a. Sri Chinmoy Answers, Volume I, Books 1-19, 2nd ed. Oxford: Ganapati Press.

Chinmoy, Sri. 2015b. Sri Chinmoy Answers, Volume II, Books 20-38, 2nd ed. Oxford and Lyon: Ganapati Press.

Clayton, Philip. 2010. Panentheisms East and West. Sophia 49(2): 183-191.

Greenough, Paul R. 1982. Prosperity and Misery in Modern Bengal: The Famine of 1943-1944. Oxford: Oxford University Press. Gupta, Nolini Kanta. 1970. An Introduction to the Vedas. Translated by Chinmoy from the Original Bengali in "Rishi Madhuchchhandar Mantramala". Pondicherry: Sri Aurobindo Ashram.

Hartshorne, Charles and William L. Reese (eds.). 2000 [1953]. Philosophers Speak of God, $2^{\text {nd }}$ ed. Amherst: Humanity Books. Moore Gerety, Finnian McKean. 2015. This Whole World Is OM: Song, Soteriology, and the Emergence of the Sacred Syllable. Doctoral dissertation, Harvard University, Graduate School of Arts and Sciences. Available at http://nrs.harvard. edu/urn-3:HUL.InstRepos:17467527. Accessed 24 Sept 2016.

Murphy, Michael. 2014. The Emergence of Evolutionary Panentheism. In Panentheism across the World's Traditions, ed. Loriliai Biernacki and Philip Clayton, 177-199. New York: Oxford University Press.

Olivelle, Patrick. 2006. Heart in the Upanișads. Rivista di Studi Sudasiatici I: 51-67. 
Pedersen, Kusumita P. 2006. The Nature of God in the Philosophy of Sri Chinmoy. ARC, The Journal of the Faculty of Religious Studies, McGill University 34: 159-180.

Pedersen, Kusumita P. 2011. Sri Ramakrishna and Sri Chinmoy. Prabuddha Bharata or Awakened India 116(1): 109-114 Pedersen, Kusumita P. 2010a. Sri Chinmoy's Contributions to Interreligious Harmony. In United in Diversity, eds. Tapan Camilla de Rozario, Eva Sadia Saad and M. Tazaddin. Dhaka: Centre for Interreligious and Intercultural Dialogue (CCID), University of Dhaka.

Pedersen, Kusumita P. 2010b. "Sri Chinmoy's Work at the United Nations: Spirituality and the Power of Silence." CrossCurrents 60 (3): 339-51.

Stensell, Ellen, and Stephen H. Phillips. 2010. Hartshorne and Indian Panentheism. Sophia 49(2): 285-295.

The Gospel of Sri Ramakrishna. 1984 [1942]. Translated and with an introduction by Swami Nikhilananda. New York: Ramakrishna-Vivekananda Center.

Vivekananda, Swami. 1979. Collected Works, $9^{\text {th }}$ edition. Volume 3, Calcutta: Advaita Ashrama.

Submit your manuscript to a SpringerOpen ${ }^{\circ}$ journal and benefit from:

- Convenient online submission

- Rigorous peer review

- Immediate publication on acceptance

- Open access: articles freely available online

- High visibility within the field

- Retaining the copyright to your article

Submit your next manuscript at $>$ springeropen.com 